\title{
LITERATURE REVIEW: SELF AWARENESS OF BADUY NONOMAN
}

\author{
Ibrahim Al Hakim ${ }^{1}$, Deasy Yunika Khairun ${ }^{2}$
}

Final Received: $23^{\text {th }}$ June 2020

Final Proof Received: $29^{\text {th }}$ March 2020

\begin{abstract}
This article aims to describe the self-awareness of Baduy nonoman (adolescents). This article uses a literature review method. Literature is obtained from various articles. The analysis unit in this article is written documents about self-awareness research in the form of journal articles and research reports through an online journal database. "Self-awareness" and "nonoman-baduy" are used as keywords in the search for articles. The article is reviewed and analyzed to explain the self-awareness of Baduy nonoman. The results of the study indicate that the self-awareness of Baduy nonoman is the result of their view of life that is rooted in Sunda Wiwitan. This article contains a description of the career commitments of students in Baduy subculture.
\end{abstract}

Keywords: literature review, self-awareness, the baduy, multicultural, guidance and counseling

JOMSIGN: Journal of Multicultural Studies in Guidance and Counseling

Website: http://ejournal.upi.edu/index.php/JOMSIGN

Permalink: https://ejournal.upi.edu/index.php/JOMSIGN/article/view/25686

How to cite (APA): Hakim, I., A. \& Khairun, D.,Y. (2020). Literature Review: Self Awareness of Baduy Nonoman. JOMSIGN: Journal of Multicultural Studies in Guidance and Counseling, 5(1), 10-17.

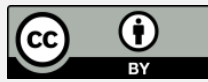

This is an open-access article distributed under the terms of the Creative Commons Attribution 4.0 International License, which permits unrestricted use, distribution, and reproduction in any medium, provided the original work is properly cited.

\section{INTRODUCTION}

Every individual wants to live a healthy and peaceful life. Therefore every person (individual) must realize and observe their level of awareness in terms of strengths, weaknesses, feelings, perceptions, thoughts, behaviors, initiations, motivations, and actions at every minute of their lives. May (Rizal, 2017) asserts the association between moral virtue and intellectual virtue. Happiness is best understood through the lens of development. Daily activities

\footnotetext{
${ }^{1}$ Universitas Sultan Ageng Tirtayasa, Indonesia, e-mail: Ibrahimhakim@untirta.ac.id

${ }^{2}$ Universitas Sultan Ageng Tirtayasa, Indonesia, e-mail: deasyyunikakhairun@unitirta.ac.id
} 
like chores, education, sports, and so on, cannot be done effectively without self-awareness.

Nonoman (adolescents) is a journey from childhood to adulthood. Nonoman should pay attention to and manifest themselves in self-actualization and self-awareness because a productive life starts from pre-teens. They should have the values of a better life, a healthy personality, and life competence capacity, i.e. moral and ethical behavior, socially responsible attitude, intellectual personality for personal growth and easier life.

Self-awareness is realized through authentic evaluation of the capacity of an individual, and the ability to recognize oneself as a separate individual from the environment and other individuals (Kalaiyarasan \& Solomon, 2016). Self-awareness also represents the capacity to be the object of one's concern. In this situation, someone actively identifies, processes, and stores information about themselves (Morin, 2011).

The Baduy tribe is one of the real examples of tribes who still preserve their ancestral teaching. Customary rules are a life guideline for each individual in carrying out the life they live. The Baduy people who exist for centuries are still trying to maintain and preserve their ancestral teaching (Pikukuh Karuhunan) from generation to generation as a symbol of their tribal cultural civilization, including in the field of education. To this day, the Baduy community still rejects the existence of formal education in their customary land and forbids the community to attend formal education. This article provides the main information about the development of self-awareness in Baduy nonoman.

\section{METHOD}

This article uses a literature study or literature review (LR). The literature review is used to enhance article synthesis by introducing a systematic, transparent, and reproducible literature-review process.

To get appropriate and high-quality articles, the right strategy is needed. The article search strategies in this study are: finding alternative spellings and synonyms, verifying keywords in each appropriate paper by using Boolean Operators, and finding the articles from the journal database of Google Scholar. The first step in the process is to determine the scope of the article to be a search process. By determining the right terms, the opportunity to get high-quality articles are bigger. The main keywords are taken from the 
research questions: ("kesadaran diri remaja") AND ("Baduy") OR ("Remaja Baduy").

The articles are selected by the deletion of duplicate articles first. 1230 titles and abstracts found from the first search are then filtered by a reviewer to discard articles that do not meet the criteria. The first selection process of articles that are considered appropriate and good amounted to 50 articles. These 50 remaining articles are then fully reviewed until 10 articles are deemed feasible and appropriate to be used in the process of literature review.

\section{FINDING DISCUSSIONS}

Self-awareness develops through the process of self-concept maturity, which is an ability to look at all aspects of an individual (Boyd \& Bee, 2012). Selfawareness is an awareness of an individual in understanding, accepting, and managing all of the potentials for their future life (Goleman, 1999). A positive self-awareness drives someone to be able to accept the reality of life (selfacceptance) (Brill, 2000), due to their ability to recognize all their potential strengths and weaknesses (Thomasson, 2006).

The stages of self-awareness in adolescents are largely characterized by two characteristics (Loevinger, 1987). First, developing the self-awareness and the capacity to imagine various possibilities in Indonesia. Second, a stable position in adulthood which is marked by the development of self-awareness and self-criticism. Adolescents are getting closer to meet the norm and the expectation. Loevinger also illustrates that at this stage, adolescents have a deep interest in interpersonal relationships.

Some experts associate self-awareness with self-consciousness (Auzolt \& Hardy-Massard, 2014). In principle, self-awareness is closely related to self-understanding and self-acceptance. With self-awareness, an individual tries to find out their strengths and weaknesses in all aspects of life (Thomasson, 2006). People who have self-awareness are those who successfully identify themselves to their life experiences (Andren, 2012).

For an individual, self-awareness serves to control all emotions so that they can be utilized in establishing social relationships with others (Auzolt \& Hardy-Massard, 2014). They must be able to control themselves from negative emotional traits, and emphasize the positive things in order to keep social relationships with others. In addition, self-awareness also serves to control 
their needs and to successfully overcome the problem (coping skills) (Duval \& Silvia, 2002).

Solso (Andren, 2012) mentioned the characteristics of self-awareness, including attention, wakefulness, architecture, recall of knowledge, and emotive. (1) Attention is the concentration of mental resources to external and internal matters. Individuals pay attention to an object from outside themselves to get an awareness of responsibility. In addition to external cues; individuals can divert attention to the self and reflect on personal thoughts, morphology, ideals, so that self-awareness will be formed. (2) Wakefulness or readiness is a mental condition experienced by someone throughout their lives, every day. (3) Architecture, an aspect of physical structure, where consciousness is not a single process carried out by a single neuron, but is maintained through a number of neurological processes associated with the interpretation of sensory, motoric, cognitive, and emotional phenomena, which exist both physically and imaginatively. These actions appear to be automatic as a result of experience. Other actions require conscious and complex intervention. (4) Recall of knowledge is the process of taking information about oneself and the world around him. Awareness enables humans to gain access to knowledge through a process of recall and recognition of information about themselves and about the world. (5) Emotive is a conscious condition, in the form of feeling or emotion. Emotion is brought on by internal conditions as a respond to external events. The subjective emotions that one expresses to others will reflect exactly as to what they feel.

There is a difference in someone paying attention to their private aspects and to the public aspects. This difference is called "public self-awareness" versus "private self-awareness" (Heintzelman \& King, 2014). Private selfawareness is a condition where attention is focused on one's own thoughts and feelings, while public self-awareness is a condition where attention is focused on the impressions and other people (Romlah, 2006). People with high private awareness seem to have better self schemes, and they are more aware of their internal dispositions. When the public self becomes very prominent, people tend to pay attention to their personal attitudes, but when attention is diverted to the outside, they might pay more attention to social norms. Public selfawareness and private self-awareness are intertwined. People can be both simultaneously (Dewi, 2013). 
The self-awareness of Baduy nonoman is built on the outlook on life (world view). The Baduy people's world view are rooted in Sunda Wiwitan. The core of this belief is shown by the existence of pikukuh or the absolute customary rules. Pikukuh are the rules and the way how it should be (mandatory) to travel as mandated ancestor lived. Pikukuh is a customary provisions that guide the activities of Baduy people as mandated by their karuhun (ancestors). Until now the Baduy society should not change and violate anything (taboo) as determined by the great-grandfather ancestors. Buyut (rigid taboo) is the violations of the pikukuh. Buyut is not codified in the form of text, but incarnates in the daily actions of the Baduy people in interacting with their fellow humans, the environment and their God. Buyut in the Baduy community are as follows:

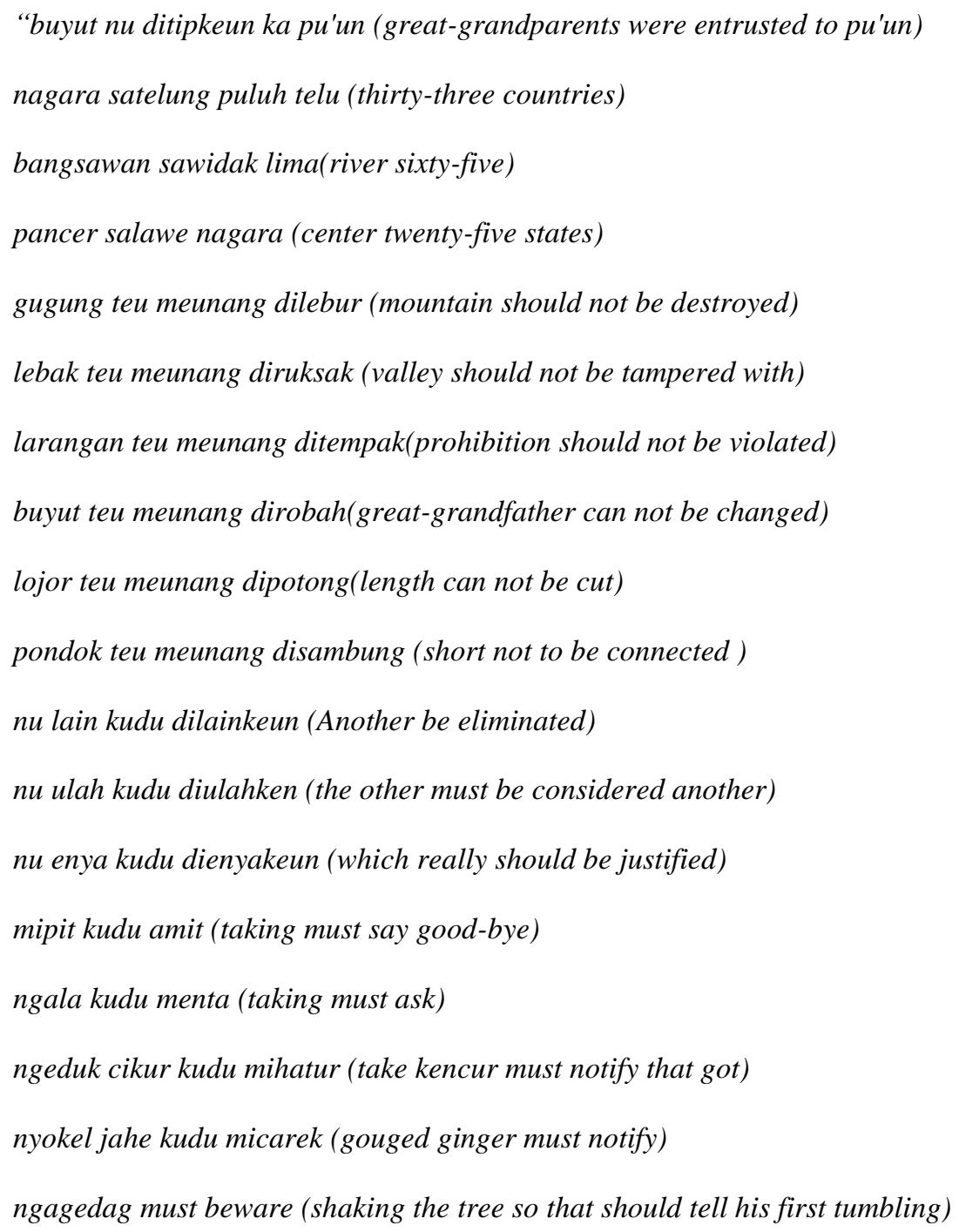


nyaur kudu diukur (speak should be measured)

nyabda kudu diunggang (said to be well thought out so that does not hurt)

ulah ngomomg sageto-geto (do not talk carelessly)

ulah lemek sadaek-daek (do not talk casually)

ulah mailng papanjingan (do not steal despite shortcomings)

ulah jinah papacangan (do not fornication and dating)

kudu ngadek sacekna (must hew exactly)

nilas saplasna (slashing setebasnya)

akibatna (consequently)

matak burung jadi ratu (could fail to be a leader)

matak edan jadi menak (crazy can be aristocrat)

matak pupul pengaruh (can be lost influence)

matak hambar komara (could be lost authority)

matak teu mahi juritan (could lose a fight)

matak teu jaya perang (could lose war)

matak eleh jajaten (can be lost courage)

matak eleh kasakten (can be lost magic)",

(Permana, 2006)

The Baduy nonoman try to control their needs and to successfully overcome the problem (coping skills) by obeying customary law (Garna, Orang Baduy, 1987). The sincerity and obedience of the Baduy nonoman in applying the customary law in their daily lives is a binding process of clairvoyance. Hence customary law for them is not a theory or opinion to be further discussed. However, there is also the law that must be obeyed and at the same time applied in every aspect of their lives so that customary law serves as a decoration and clothing that is closely attached to their daily lives without exception. The Baduy nonoman believe that customary law must be obeyed and implemented. Once the law is violated they will get a curse from 
the Creator and ancestors (guriang leluhur) and consequently, they will live in misery (Sam \& Suhandi, 1986).

\section{CONCLUSION AND RECOMMENDATION}

The Baduy nonoman believe that they must have an outlook of life in order to understand, accept, and manage all their potentials for their future lives. Their outlook of life come from their ancestors. The Baduy nonoman's selfawareness are the result of ancestral teachings rooted in Sunda Wiwitan. The limitation of this study lies in the disclosure method which is a direct empirical data. Recommendations for further studies are the need to use interview techniques as well as in-depth questionnaires to get more comprehensive data in revealing the self-awareness of Baduy nonoman.

\section{ACKNOWLEDGEMENTS}

The author would like to thank to Dr. Mamat Supriatna, M.Pd. for his helpful advice in writing this article.

\section{REFERENCES}

Andren, U. (2012). Self-Awareness an Self-Knowledge in Professions. New York: Freeman.

Auzolt, L., \& Hardy-Massard, S. (2014). Desirability Associated with the Expression of Self-COnsciousness in a French Population. Swiss Journal of Psychology, 183-188.

Boyd, D., \& Bee, H. (2012). The Developing Child. Boston: Pearson.

Brill, R. R. (2000). Emotional Honesty an Self-Acceptance. USA: XLibris Coorporation.

Dewi, N. K. (2013). Pengembangan Model Layanan Bimbingan Kelompok Berbasis Nilai Karakter Lokal Jawa untuk Meningkatkan Kesadaran Diri (Self-Awareness) Siswa. Tesis Tidak Diterbitkan. Semarang: Program Pascasarjana Bimbingan dan Konseling Universitas Negeri Semarang.

Duval, T. S., \& Silvia, P. J. (2002). Self-Awareness, Probability of Improvement and the Self-Serving Bias. Journal of Personalitu and Social Psychology, 49-61.

Garna, J. (1987). Orang Baduy. Bangi: Universitas Kebangsaan Malaysia. 
Garna, J. (1987). Orang Baduy. Bangi: Universiti Kebangsaan Malaysia.

Garna, Judistira. (1987). Orang Baduy. Bangi: Universiti Kebangsaan Malaysia.

Garna, Permana, Sam. (t.thn.).

Goleman, D. (1995). Emotional Intelligence Why It Can Matter More Than $I Q$. New York: Bantam Books.

Goleman, D. (1995). Emotional Intelligence Why It Can Matter More Than $I Q$. New York: Bantam Books.

Goleman, D. (1995). Emotional Intelligence Why It Can Matter More Than $I Q$. New York: Bantam Books.

Goleman, D. (1999). Kecerdasan Emosi untuk Mencapai Prestasi . Jakarta: Gramedia Pustaka Utama.

Heintzelman, S. J., \& King, L. A. (2014). Life is Pretty Meaningfull. American Psychologist, 561-574.

Kalaiyarasan, M., \& Solomon, D. M. (2016). Importance of Self Awareness in Adolescence - A Thematic Research Paper. IQSR Journal of Humanities and Social Science, 19-22.

Loevinger, J. (1987). Paradigms of Personality. New York: Freeman.

Morin, A. (2011). Self Awareness Part 1: Definition, Measures, Effects, FUnctions, and Antecedents. Social and Personality Psychology Compass, 807-823.

Permana, R. (2006). Tata Ruang Masyarakat Baduy. Jakarta: Wedatama Widya Sastra.

Rizal, Y. (2017). Perilaku Moral Remaja dalam Perspektif Budaya. Jomsign: Journal of Multicultural Studies in Guidance an Counseling, 40-40.

Romlah, T. (2006). Teori dan Praktik Bimbingan Kelompok. Malang: Universitas Negeri Malang.

Sam, A., \& Suhandi. (1986). Tata Kehidupan Masyarakat Baduy i Provinsi Jawa Barat. Bandung: Departemen Pendiikan dan Kebudayaan Proyek Inventarisasi dan Dokumen Kebudayaan Daerah.

Thomasson, A. L. (2006). Self-Awareness and Self-Knowledge. Psyche, 1-15. 